\title{
THE ANALYSIS OF VARIANTS OF WATER SUPPLY SYSTEMS IN MULTI-FAMILY RESIDENTIAL BUILDING
}

\author{
ANALIZA WARIANTÓW ZAOPATRZENIA W WODE \\ WIELORODZINNEGO BUDYNKU MIESZKALNEGO
}

\begin{abstract}
Climate change, improper use of water resources, surface waters pollution as well as increase of water requirements are the results of growing population of people in the world. It causes water deficiency in majority of countries in the world, including Poland. Due to the water pollution advanced technologies for its treatment are in demand, what leads to increase of water price. In this connection, there are more often taken actions to reduce water consumption by using rainwater to flush toilets, wash cars, do laundry or water green areas. This publication presents results of Life Cycle Cost analysis of two variants of water supply systems designed for multi-family residential building situated in Rzeszow. In line with LCC methodology the calculations were made throughout the whole life-cycle of the building considering initial investment outlays intended for construction of water supply system as well as operation and maintenance costs. In the first of analyzed variants it was assumed that the system would be fed by municipal water supply network. In the second variant rainwater harvesting system for domestic use was additionally applied. Rainwater stored in the tank would be used in sanitary installation to flush toilets, what leads to lowering the costs of municipal water purchase, reducing fees for rainwater discharge to sewage system and consequently is beneficial for financial standing of the examined building.
\end{abstract}

Keywords: water supply in buildings, Life Cycle Cost analysis, rainwater harvesting systems

\section{Introduction}

In the times of changing climate and progressing urban development, the growing problem faced throughout the world is connected with ensuring adequate quantity and quality of potable water [1-3]. Additionally, the rapid processes of urbanization contribute to the growth of populations in cities [4]. According to data of the United Nations Population Division, by 2030 urban populations of the world will increase by $1,750,000,000$ people [5], and by 2050 the total population of the world will increase to 9.3 billion [6]. Similarly, urbanization, whose consequences include depletion of green areas, arable lands, and forests as well as decrease in the biological diversity of species,

\footnotetext{
${ }^{1}$ Department of Infrastructure and Sustainable Development, Faculty of Civil and Environmental Engineering, Rzeszow University of Technology, al. Powstańców Warszawy 12, 35-959 Rzeszów, Poland, phone +48 1786511 51, fax +48 17865 1172, email: daniels@ prz.edu.pl

*Corresponding author: stec_aga@prz.edu.pl
} 
leads to considerable deterioration of the quality of air and water, not only locally but also at the regional and global level [7, 8]. Urbanization is the main driving factor causing both global changes and degradation of the natural environment and contributes to rapid depletion of its resources $[9,10]$. Therefore, the natural environment's resources, including water, should be managed in sustainable manner.

Because of the growing demand for potable water resulting from the increase in the world's population and due to the depletion of freshwater resources, most countries, including Poland, are faced with the deficit of water. According to the World Health Organization as many as 884 million people throughout the world do not have access to a safe source of drinking water [11], and each year over 5 million people die due to the lack of water or as a result of diseases caused by consumption of poor quality water [12]. Because of this a variety of measures are taken continuously in order to reduce the depletion of the global water resources, $e g$ by using recycled water [13-16], installing high-efficiency appliances [16] and using rainwater in toilet flushing, car washing, washing machines, irrigation of arable land or watering green areas [18-22].

Systems designed for collecting and reusing water have been applied for years throughout the world. Depending on the country, climate conditions, type of building in which the system based on rainwater has been installed, savings in consumption of mains water may be as high as $100 \%$ [23]. Systems of this type are also recommended by the European Commission for application in sanitary installations of civil engineering structures [24].

Given the fact that they can reduce the flow of rainwater into sewers, thereby impacting the related hydraulic load, these systems have become an integral part of sustainable stormwater management [25].

For many years now, researchers throughout the world have viewed rainwater harvesting $(\mathrm{RWH})$ is one of the strategies allowing the sector of water management to adjust to the changing climate [26-28].

Rainwater can be used for toilet flushing not only in residential buildings [29-32], but also in large sports facilities [33], university facilities [34], supermarkets [35] and office buildings [36].

Zhang et al [16] conducted simulation tests measuring the use of rainwater and greywater in residential buildings in the township of Cranbrook, Western Australia. In the study they used Aquacycle computer program taking into account the water supply system, storm water run-off and wastewater disposal. Savings in scheme water supply were up to $32.5 \%$ when greywater was reused and $25.1 \%$ when rainwater was used for flushing toilets and watering gardens [16]. Similar analyses were conducted by Coombes et al [37] for another location in Australia. This study took into account 27 residential buildings situated in Newcastle. The findings showed that, for the analyzed factors, $60 \%$ of the demand for water in these buildings could be covered by rainwater [37].

Eroksuz and Raham [38] reported that large rainwater tanks with capacity up to $70 \mathrm{~m}^{3}$ could provide $50 \%$ of water needed for flushing WCs, doing laundry and watering plants in large residential buildings.

On the other hand, Abdulla and Al-Shareef [39] showed that RWH systems could save only from 0.27 to $19.7 \%$ of water demand in residential buildings located in Jordan.

Furthermore, Ghisi and de Oliveira [29] conducted simulation tests for the use of rainwater for laundry and for flushing WCs in residential buildings in southern Brazil. They 
took into account two houses with rainwater tanks, the capacity of 3000 and 5000 litres. Savings related to water supply amounted to 33.6 and $35.5 \%$ respectively [29]. When a larger number of houses, ie the total of 62 buildings were taken into account, rainwater could cover the demand at the level ranging from 34 to $92 \%$. The savings depended on the demand for potable water in the specific buildings [40].

In Germany systems designed for collecting and using rainwater have been applied in residential buildings and public facilities since 1980s. Hermann and Schmida [41] estimated that an average household could reduce its demand for potable water by $30-60 \%$ if rainwater was used for flushing WCs.

The largest rainwater harvesting system in Germany was built at the Frankfurt airport. Rainwater is conducted from the roof with the surface of $26,800 \mathrm{~m}^{2}$ to six tanks with the capacity of $100 \mathrm{~m}^{3}$, which allows for saving on average $1,000,000 \mathrm{~m}^{3}$ of water per year. The system is mainly used for flushing toilets and watering plants [42].

Souza and Ghisi [43] conducted research focusing on the possibilities to reduce consumption of potable water in residential buildings located in 13 selected cities worldwide, eg Moscow, New York, Barcelona, Berlin, Alexandria and Shanwei. For each of these cities they investigated the impact of such factors as precipitation rate, type of drainage basin and size of the population on the choice of optimum size rainwater tank. They showed that because all investigated parameters significantly impact the design of RWH systems, it is necessary to conduct separate measurements for buildings located in various places on a case-by-case basis.

In Japan systems collecting rainwater were built at three large sports facilities: Tokyo Dome, Fukuoka Dome and Nagoya Dome and are mainly used for flushing toilets. In these facilities water flowing down from the roofs is stored in tanks with the capacity of 1,000 , 1,800 and $1,500 \mathrm{~m}^{3}$ respectively. Zaizen et al [33] have reported that in the case of Fukuoka Dome the system covers over $65 \%$ of the demand for water of lower quality. This kind of system was also installed at Kokugikan sports stadium in Tokyo. Water from a $750 \mathrm{~m}^{3}$ tank is used not only for flushing WCs but also in a cooling-water installation [18].

In Poland systems using rainwater for toilet flushing are a rarity. However, results of analyses focusing on the possibility of applying such systems in residential buildings have been presented in a number of publications [44, 45].

The present publication discusses results of Life Cycle Cost (LCC) analysis for two options of water supply scheme envisaged for a multi-family residential building located in Rzeszow. The first option assumed that the facility would be provided with water exclusively under the municipal supply scheme. The second option envisaged an additional installation designed for household use of rainwater. Collected in a tank, rainwater would be used in sanitary installations for flushing toilets, which would allow for reducing costs of water purchased under the supply scheme, and for cutting down the fees for discharging stormwater to sewers; this in turn would beneficially impact the financial results of operating the residential building in question.

\section{Research question}

The multi-family building in question is located in Rzeszow. It is a 4-story structure with a basement and it consists of two segments. The flats are arranged in the following 
way: in both segments there are 3 flats per floor on the ground, first and second level; on the third floor there are 2 flats in segment I and 3 flats in segment II.

The financial analysis of the adopted options for water supply scheme in the above building was based on the following essential data:

- number of residents: 81 ,

- roof surface: $455 \mathrm{~m}^{2}$,

- demand for water for flushing toilets in the building: $2.835 \mathrm{~m}^{3} / \mathrm{d}$.

The calculations were based on historical data for rainfall rates in Rzeszow during 10 years. Average annual precipitation in the period was $612 \mathrm{~mm}$.

\section{Model of the system}

In the case of residential buildings, the installation for domestic use of rainwater consists of the following components:

- roof draining system (roof gutters and drain pipes),

- appliances for rainwater treatment,

- lower storage tank with overflow system,

- upper storage tank,

- pumping system,

- water supply installation to supplement shortage of rainwater,

- installation distributing rainwater in the building,

- measurement and control instruments, anti-contamination equipment.

Figure 1 presents the general layout of the system designed for utilizing rainwater in the residential building.

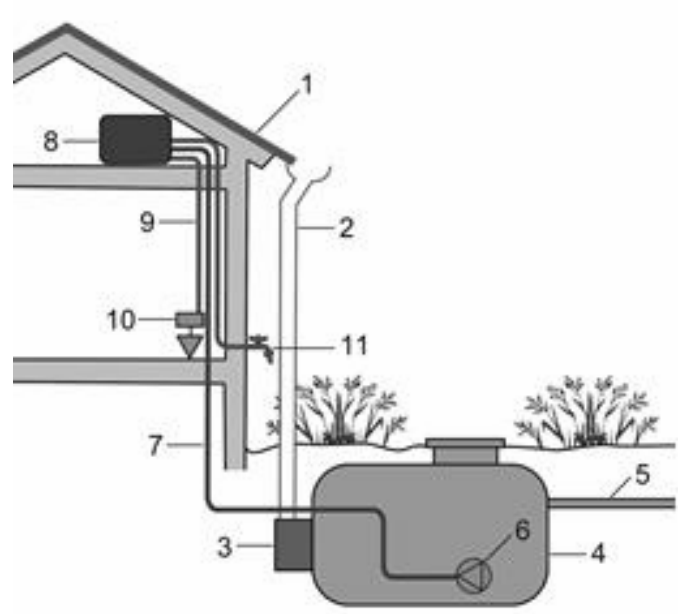

Fig. 1. Layout of the system designed for utilizing rainwater in the residential building: 1 - roof surface, 2 - roof gutters and drain pipes, 3 - pre-treatment installation, 4 - lower storage tank, 5 - emergency overflow, 6 - pumping system, 7 - upper tank inlet installation, 8 - upper storage tank, 9 - installation carrying water to sanitary fittings, 10 - sanitary fittings, 11 - installation carrying water to other fittings 
Given the connection between the roof draining system, lower storage tank and emergency overflow as well as the designed use of rainwater, the following configuration of the installation system can be applied [23, 31, 41, 44-46]:

- installation with a flow-through tank and duct releasing excess water to sewers,

- installation with a flow-through tank and devices for excess water infiltration,

- installation with distribution valve and duct releasing excess water to sewers,

- installation with distribution valve and devices for excess water infiltration,

- $\quad$ installation with storage tank for accumulating all rainwater.

\section{Simulation model}

The computational model comprises the system of collecting, storing and utilization of rainwater. Its operation is determined by such factors as: occurrence of precipitation, size of retention tank, volume of water collected in the tank, size of the roof surface and runoff coefficient as well as demand for water of lower quality. The model is presented schematically in Figure 2.

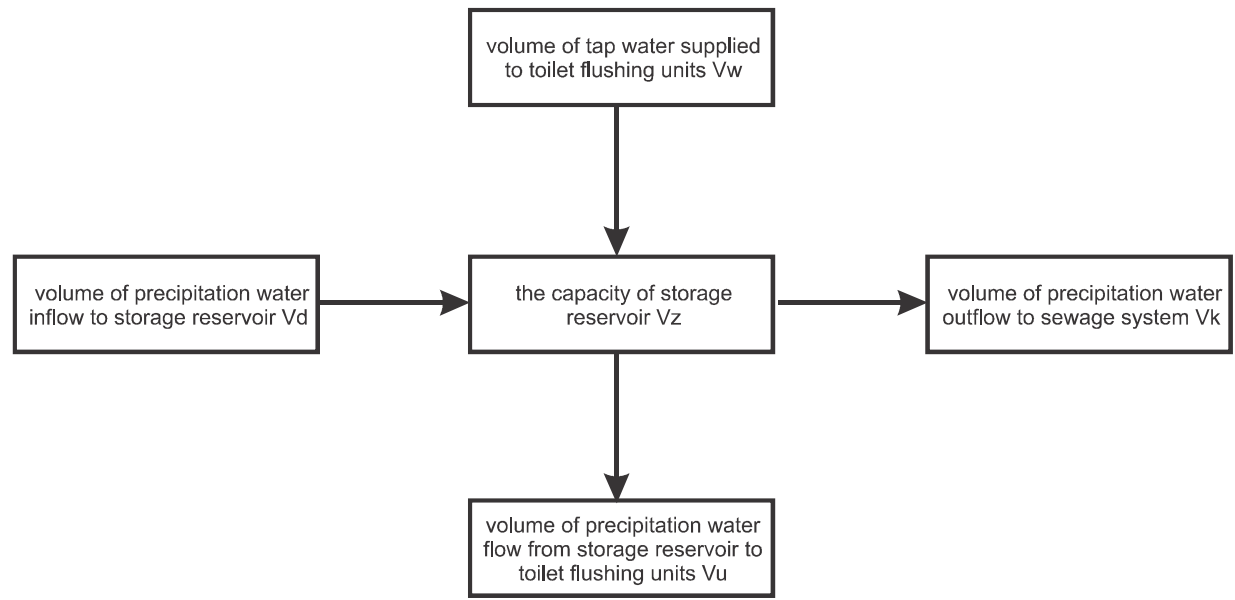

Fig. 2. Model of the system for utilization of rainwater, $V d$ - volume of precipitation water inflow to storage reservoir, $V k$ - volume of precipitation water outflow to sewage system, $V u$ - volume of precipitation water flow from storage reservoir to toilet flushing units, $V w$ - volume of tap water supplied to toilet flushing units, $V z$ - the capacity of storage reservoir

The performance of the system is described with the following conditions which determine the processes of rainwater flow, its accumulation and release of water to sanitary installation and sewers.

- Filling in and accumulation of rainwater in the retention tank:

If $V r k_{i}+V d_{i+1}>V z$ to $V_{i+1}=V z, i=1,2, \ldots, n$

If $V r k_{i}+V d_{i+1} \leq V z$ to $V_{i+1}=V r k_{i}+V d_{i+1}, i=1,2, \ldots, n$

- Rainwater intake from the retention tanks by the installation:

If $V r p_{i}-V s<0$ to $V r k_{i}=0$ and $V u_{i}=V r p_{i}, i=1,2, \ldots, n$

If $V r p_{i}-V s \geq 0$ to $V r k_{i}=V r p_{i}-V s$ and $V u_{i}=V s, i=1,2, \ldots, n$ 
- $\quad$ Flow of mains water to the tank:

If $V r p_{i}>V s$ to $V w_{i}=0, i=1,2, \ldots, n$

If $V r p_{i} \leq V s$ to $V w_{i}=V s-V r p i, i=1,2, \ldots, n$

- Discharge of rainwater from the retention tank to sewers:

If $V r p_{i}+V d_{i} \leq V z$ to $V k_{i}=0, i=1,2, \ldots, n$

If $V r p_{i}+V d_{i}>V z$ to $V k i=V r k_{i}+V d_{i}-V z, i=1,2, \ldots, n$

where: $V_{i}$ - volume of rainwater retained in the tank at the end of day $i$ (no.) $\left[\mathrm{m}^{3}\right]$; $V d_{i}$ - volume of rainwater inflowing on day $i$ (no.) $\left[\mathrm{m}^{3}\right] ; V r k_{i}$ - volume of retained rainwater in the tank after intake by installation on day i (no.) $\left[\mathrm{m}^{3}\right] ; \operatorname{Vrp}_{i}$ - volume of rainwater retained in the tank before intake by installation on day $i$ (no.) $\left[\mathrm{m}^{3}\right] ; V s$ - volume of water utilized by installation $\left[\mathrm{m}^{3}\right] ; V u$ - volume of rainwater inflowing from retention tank to installation $\left[\mathrm{m}^{3}\right] ; V w_{i}$ - volume of mains water transported to installation on day $i$ (no.) $\left[\mathrm{m}^{3}\right]$.

\section{Financial model}

Financial analysis of options for water supply in the multi-family building was based on Life Cycle Cost methodology. In accordance with LCC methodology the calculations were performed taking into account the complete life cycle of the building, including the initial investments designated for constructing the water supply system and the costs connected with its use. At present LCC cost analysis is employed in various sectors of economy, eg power engineering, various industries, transport, construction, infrastructure and pumping systems. It is mainly used as a tool in decision-making and management processes [47, 48]. Results of LCC analysis can provide valuable information and facilitate decisions in the process of assessing and comparing alternative solutions. In many countries Life Cycle Cost methodology is required by the law in the case of new investments, particularly those projects which involve high initial expenditure and long operation time.

Ghimire et al [49] conducted LCC financial analysis for the application of rainwater harvesting systems for flushing toilets in industrial facilities. They also calculated Net Present Value Benefits (NPVB) for these systems. Based on the obtained results they concluded that RWH systems are not economical for the buildings in question [49].

On the other hand Farreny et al [50] employed Life Cycle Cost analysis to identify total costs of collecting and utilizing rainwater in multi-family residential buildings located in Spain. They assessed two scenarios for water pricing: the current prices and prices taking into account future growth in costs of water. The findings show that RWH systems employed in densely populated areas with Mediterranean climate are beneficial from the standpoint of economy only when certain assumptions are adopted, specifically if it is assumed that the prices for mains water are going to increase [50].

In the UK financial analysis was conducted for 384 installations for harvesting and utilization of rainwater which had been built in that country. For that purpose Life Cycle Cost methodology was applied and various scenarios of future costs connected with operating such installations were taken into account. In each case it was shown that rainwater harvesting was significantly less cost-effective than supplying the same buildings exclusively with water from the network [51].

Due to the above, the present article describes tests which make it possible to estimate the costs of building and operating RWH systems in Poland. For each of the water supply 
options envisaged by the study for the multi-family building and for the assumed life of the building in question, the LLC costs were determined according to:

$$
L C C=K_{I}+\left[\sum_{t=1}^{T}(1+r)^{-t}\right] \cdot K_{E}
$$

where: $K_{I}$ - financial investment [PLN], $K_{E}$ - operation costs [PLN], $T$ - duration of LCC analysis, $T=30$ years, $r$ - constant discount rate, $r=0.05, t$ - successive year of using the building [-].

LCC analysis was conducted for the following options concerning transport of water to the installation designed for flushing toilets in the residential facility in question:

- Option I - providing the internal installation exclusively with water supplied by the mains.

- Option II - providing the internal installation additionally with water collected from the building's roof and stored in a tank located in the basement.

The capacity of the rainwater storage tank was calculated taking into account the demand for water for flushing WCs and amounted to $V z=22 \mathrm{~m}^{3}$.

For the first option, the operation costs $K_{E I}$ included costs of purchasing water from the water supply network and the costs of discharging all stormwater from the roof to sewers. These costs were calculated following formula:

$$
K_{E I}=K_{Z W W}+K_{O W D}
$$

where: $K_{E I}$ - operation costs for Option I water supply system in the building [PLN], $K_{Z W W}$ - cost of purchasing water for flushing WCs [PLN], $K_{O W D}$ - cost of discharging rainwater to sewers [PLN].

The second case took into account operation costs $K_{E I I}$ connected with the purchase of mains water necessary for filling up the tank if the flow of rainwater from the roof does not cover the demand for water needed for flushing toilets, and the costs of discharging excess rainwater to sewers. Additional costs were connected with the transport of water from the tank, via pumps to water-closet bowls. The calculation of operation costs $K_{E I I}$ was based on formula:

$$
K_{E I I}=K_{Z W W}+K_{O W D}+K_{P W}
$$

where: $K_{E I I}$ - operation costs for Option II water supply system in the building [PLN], $K_{P W}$ - cost of transporting water from the tank, via pumps to water-closet bowls [PLN].

Operation costs $K_{P W}$ connected with transporting water for flushing toilets via the pump system was determined from relationship:

$$
K_{P W}=c_{e n} \frac{V_{W} \cdot \rho \cdot g \cdot H}{\eta_{p} \cdot 3.6 \cdot 10^{6}}
$$

where: $c_{e n}$ - unit price for electrical energy [PLN/kWh], $V_{W}$ - annual volume of water transported from the tank via the pumping system to water-closet bowls $\left[\mathrm{m}^{3} /\right.$ year], $\rho$ - density of waste water $\left[\mathrm{kg} / \mathrm{m}^{3}\right], g$ - gravitational acceleration $\left[\mathrm{m} / \mathrm{s}^{2}\right], H$ - pumping height $[\mathrm{m}], \eta_{p}$ - pumping system efficiency [-].

Additionally calculation of operation costs for each water supply option envisaged for the building took into account annual increase in prices of purchasing mains water and 
electricity as well as costs of discharging rainwater to sewers. Based on projections, the following values were determined:

- $\quad$ increase in purchase prices for water from water mains, $r_{w}=0.08$;

- $\quad$ increase in purchase prices for electricity, $r_{e}=0.07$;

- $\quad$ increase in prices for discharging rainwater to sewers, $r_{d}=0.04$.

The calculations of the total costs of construction and using the installation transporting water for flushing WCs additionally took into account the following data:

- $\quad$ purchase price for $1 \mathrm{~m}^{3}$ of mains water, $c_{w}=4.17$ PLN;

- $\quad$ price for discharging $1 \mathrm{~m}^{3}$ of rainwater to sewers, $c_{w d}=3 \mathrm{PLN}$;

- annual volume of water transported to toilets: $1034.78 \mathrm{~m}^{3}$;

- annual volume of rainwater transported via pumping systems to water-closet bowls: $245.8 \mathrm{~m}^{3}$;

- $\quad$ purchase price for electricity, $c_{e n}=0.60 \mathrm{PLN} / \mathrm{kWh}$.

\section{Analysis of test results}

The applied simulation model of installation designed for domestic use of rainwater to flush toilets in the building in question, as well as the LCC cost analysis conducted for two options of water supply in that building, showed that for the data taken into account in the calculations the traditional method of providing the building with water exclusively from the mains is a cheaper alternative. The obtained findings are shown in Table 1.

Table 1

Comparison of costs for the envisaged options of water supply in a multi-family building, with $8 \%$ increase in water pricing

\begin{tabular}{|c|c|c|c|c|c|}
\hline \multirow[b]{2}{*}{$\begin{array}{l}\text { Water supply } \\
\text { option }\end{array}$} & \multirow{2}{*}{$\begin{array}{c}\text { Capital } \\
\text { expenditures } \\
N_{I N W}[\text { PLN] }\end{array}$} & \multicolumn{3}{|c|}{ Operation costs $K_{E}[\mathrm{PLN}]$} & \multirow[b]{2}{*}{$\begin{array}{c}\text { LCC costs } \\
\text { [PLN] }\end{array}$} \\
\hline & & $\begin{array}{l}K_{\text {ZWW }} \\
{[\mathbf{P L N}]}\end{array}$ & $\begin{array}{c}K_{O W D} \\
{[\text { PLN] }}\end{array}$ & $\begin{array}{c}K_{P W} \\
{[\text { PLN] }}\end{array}$ & \\
\hline & 203,629 & $206,301.58$ & $20,898.83$ & - & 29.41 \\
\hline Option II & 278,383 & $157,327.80$ & $1,764.08$ & $1,441.84$ & $438,916.72$ \\
\hline
\end{tabular}

Analysis of the findings allows for the conclusion that Option I is characterised by initial capital expenditure which is $27 \%$ lower than Option II. On the other hand, Option I operation costs exceed Option II operation costs by $30 \%$. The greater value of investments in the latter option results from the necessity to use additional components, such as storage tank, pumping system, fittings and ducts, which are not applicable in the standard installation. The most capital-intensive component of the installation designed for domestic use of rainwater is the storage tank.

However, given the LCC costs, the findings show that the cost of Option II is less than $2 \%$ higher if compared with Option I. Therefore, in the long-term perspective overall costs of both options are similar.

\section{Analysis of price-change scenarios}

Based on historical data for the most recent decade, showing the increase in purchase prices for mains water in Rzeszow, the study assumed annual $8 \%$ increase for these prices. However, in order to assess the impact of uncertainty of data on the financial parameters of 
investment we performed an analysis of related cost-effectiveness taking into account various scenarios of increase in prices for mains water. Due to this the study assumed additional scenarios for the increase in prices by 6 and 10\%. The related findings are shown in Tables 2 and 3, respectively.

Table 2

Comparison of costs for the envisaged options of water supply in a multi-family building, with $6 \%$ increase in water pricing

\begin{tabular}{|c|c|c|c|c|c|}
\hline \multirow{2}{*}{$\begin{array}{c}\text { Water supply } \\
\text { option }\end{array}$} & $\begin{array}{c}\text { Capital } \\
\text { expenditures } \\
N_{I N W}[\mathbf{P L N}]\end{array}$ & \multicolumn{3}{|c|}{ Operation costs $\boldsymbol{K}_{\boldsymbol{E}}[\mathbf{P L N}]$} & \multirow{2}{*}{ [ } \\
\cline { 3 - 5 } & {$[\mathbf{P L W}]$} & $\begin{array}{c}\boldsymbol{K}_{\boldsymbol{O} W \boldsymbol{D}} \\
{[\mathbf{P L N}]}\end{array}$ & $\begin{array}{c}\boldsymbol{K}_{\boldsymbol{P W}} \\
{[\mathbf{P L N}]}\end{array}$ & \\
\hline Option I & 203,629 & $150,422.04$ & $20,898.83$ & - & $374,949.87$ \\
\hline Option II & 278,383 & $114,691.02$ & $1,764.08$ & $1,441.84$ & $396,279.94$ \\
\hline
\end{tabular}

Table 3

Comparison of costs for the envisaged options of water supply in a multi-family building, with $10 \%$ increase in water pricing

\begin{tabular}{|c|c|c|c|c|c|}
\hline \multirow[b]{2}{*}{$\begin{array}{c}\text { Water supply } \\
\text { option }\end{array}$} & \multirow{2}{*}{$\begin{array}{c}\text { Capital } \\
\text { expenditures } \\
N_{I N W}[\text { PLN] }\end{array}$} & \multicolumn{3}{|c|}{ Operation costs $K_{E}[\mathrm{PLN}]$} & \multirow[b]{2}{*}{ LCC costs $[P L N]$} \\
\hline & & $\begin{array}{l}K_{Z W W} \\
{[P L N]}\end{array}$ & $\begin{array}{l}\text { KoWD } \\
\text { [PLN] }\end{array}$ & $\begin{array}{c}K_{P W} \\
{[\text { PLN] }}\end{array}$ & \\
\hline Option I & 203,629 & $288,330.47$ & $20,898.83$ & - & $512,858.30$ \\
\hline Option II & 278,383 & $219,840.91$ & $1,764.08$ & $1,441.84$ & $501,429.83$ \\
\hline
\end{tabular}

Operation costs $K_{Z W W}$ incurred in consecutive years during the life of the building were separately calculated for both investigated water supply options, taking into account the assumed scenarios of increase in water pricing. Findings for Option I and Option II are shown in Figures 3 and 4, respectively.

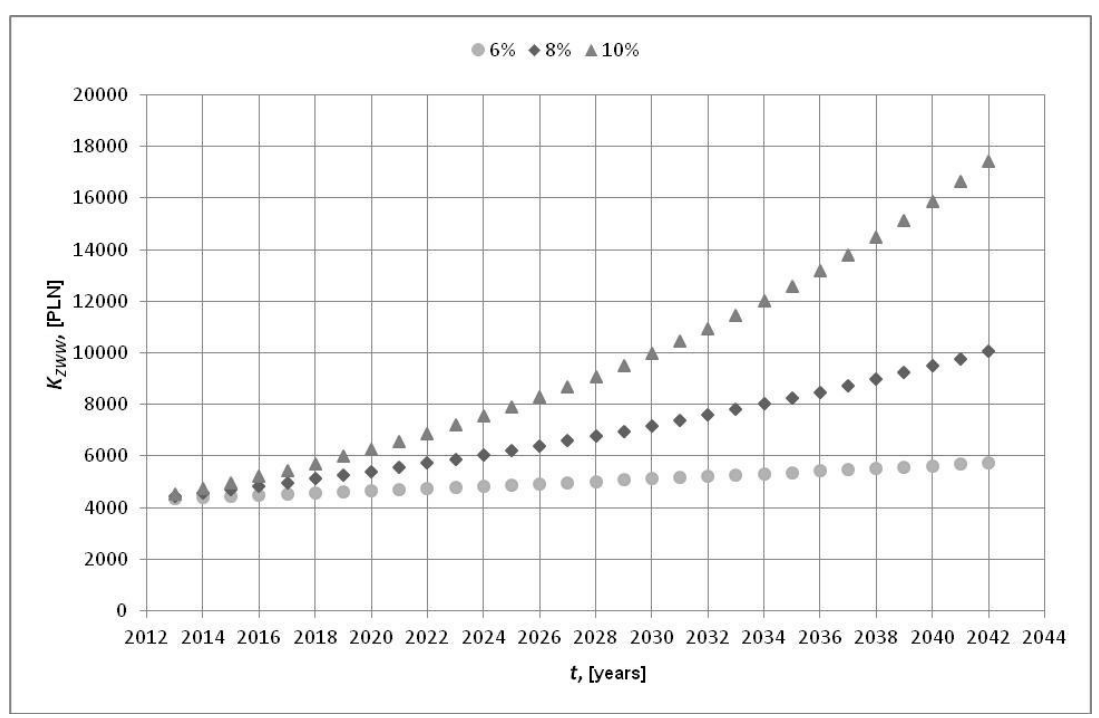

Fig. 3. Costs of purchasing mains water $K_{Z W W}$ in accordance with price-change scenarios, for Option I water supply system in a multi-family building in consecutive years subject to analysis 


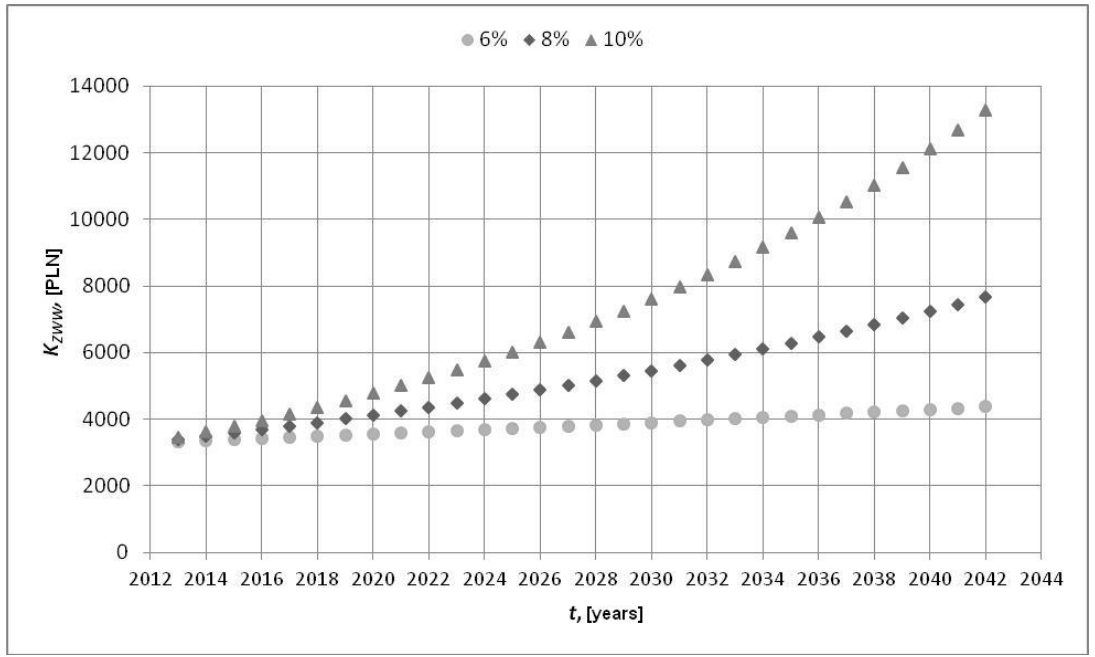

Fig. 4. Costs of purchasing mains water $K_{Z W W}$ in accordance with price-change scenarios, for Option II water supply system in a multi-family building in consecutive years subject to analysis

The findings of the study show that the level of investment profitability for the scenario assuming $6 \%$ increase in water pricing is similar to cost-effectiveness observed in the $8 \%$ increase scenario. On the other hand, for the scenario assuming $10 \%$ increase in the price of water from the mains, the overall LCC costs in Option II are over $2 \%$ lower if compared with Option I. This means that in such case the use of installation designed for domestic application of rainwater in the residential building in question is more cost-effective. The assumed $10 \%$ increase in pricing is higher than the rate based on historical data, yet if we take into account the current projections concerning water pricing and the fact that water resources in Poland are shrinking, this scenario is highly probable.

\section{Conclusions}

Harvesting and use of rainwater is highly effective from the standpoint of sustainable development of cities and is increasingly often recognized as a key measure in strategies designed to reduce the shortage of water in urban areas.

The LCC analysis conducted for two water supply options envisaged for a multi-family building showed that, in spite of its more complex installation requiring greater investments, the system designed for domestic use of rainwater in that building may be a valuable alternative to conventional systems providing buildings with water exclusively under municipal water supply schemes. The identified financial results allow for a conclusion that in longer timeframes the overall costs of both installation options are similar. Besides that, application of systems designed for collecting, storing and utilizing rainwater is highly effective from the point of view of the environment. Most importantly, this solution reduces the magnitude of transient stormwater runoffs from catchment areas and constitutes additional water reservoir. It additionally has beneficial impact on operation of combined sewers and wastewater treatment plants, and improves cost-effectiveness of urban drainage systems. 


\section{References}

[1] Carlson TN, Arthur ST. The impact of land use - land cover changes due to urbanization on surface microclimate and hydrology: a satellite perspective. Global Planet Change. 2000;25:49-65. DOI: 10.1016/S0921-8181(00)00021-7.

[2] Jenerette D, Larsen L. A global perspective on changing sustainable urban water supplies. Global Planet Change. 2006;50:202-211. DOI: 10.1016/j.gloplacha.2006.01.004.

[3] Oki T, Kanae S. Global hydrological cycles and world water resources. Science. 2006;313:1068-1072. DOI: 10.1126/science.1128845.

[4] McDonald I. Global urbanization: Can ecologists identify a sustainable way forward? Front Ecol Environ. 2008;6(2):99-104. DOI: 10.1890/070038.

[5] United Nations Population Division. World Urbanization Prospects: The 2005 Revision. New York; 2005.

[6] United Nations, Department of Economic and Social Affairs, Population Division. World Population Prospects: The 2010 Revision, Volume II: Demographic Profiles. New York; 2011.

[7] Duh D, Shandas V, Chang H, George A. Rates of urbanisation and the resiliency of air and water quality. Sci Total Environ. 2008;400(1-3):238-256. DOI: 10.1016/j.scitotenv.2008.05.002.

[8] Kennedy C, Cuddihy J, Engel-Yan J. The changing metabolism of cities. J Ind Ecol. 2007;11(2):43-59. DOI: $10.1162 /$ jie.2007.1107.

[9] Huang L, Yeh C, Chang F. The transition to an urbanizing world and the demand for natural resources. Curr Opin Environ Sustain. 2010;2:136-143. DOI: 10.1016/j.cosust.2010.06.004.

[10] Yao M, Wang C, Zhang C, Chen K, Song P. The influencing factors of resources and environments in the process of urbanization of China. Prog Geogr. 2008;27(3):94-100.

[11] WHO/UNICEF. Drinking Water Equity, Safety and Sustainability: Thematic Report on Drinking Water 2011. Joint Monitoring Programme for Water Supply and Sanitation (JMP). Geneva/New York; 2011.

[12] http://www.unic.un.org.pl/projekt_milenijny/oblicza_ubostwa.php

[13] Hurlimann A, Dolnicar S, Meyer P. Understanding behaviour to inform water supply management in developer nations - A review of literature, conceptual model and research agenda. J Environ Manage. 2009;91:47-56. DOI:10.1016/j.jenvman.2009.07.014.

[14] Miller G. Integrated concepts in water reuse: managing global water Leeds. Desalination. 2006;187:65-75. DOI: 10.1016/j.desal.2005.04.068.

[15] Miller E, Buys L. Water-recycling in South East Queensland, Australia: what do men and women think. Rural Society. 2008;18(3):220-229.

[16] Zhang Y, Grant A, Sharma A, Chen D, Chen L. Alternative water resources for rural residential development in Western Australia. Water Resour Manage. 2010;24:25-36. DOI: 10.1007/s11269-009-9435-0.

[17] Lee M, Tansel B, Balbin M. Influence of residential water use efficiency measures on household water demand: A four year longitudinal study. Resour Conserv Recycling. 2011;56:1-6. DOI: 10.1016/j.resconrec.2011.08.006.

[18] Furumai H. Rainwater and reclaimed wastewater for sustainable urban water use. Phys Chem Earth. 2008;33:340-346. DOI: 10.1016/j.pce.2008.02.029.

[19] Jones M, Hunt W. Performance of rainwater harvesting systems in the southeastern United States. Resour Conserv Recy. 2010;54:623-629. DOI: 10.1061/41009(333)30.

[20] Coombes P. Rainwater Tanks Revisited: New Opportunities for Urban Water Cycle Management. Australia: The University of Newcastle; 2003.

[21] Ghisi E, Tavares D, Rocha V. Rainwater harvesting in petrol stations in Brasilia: Potential for notable water savings and investment feasibility analysis. Resour Conserv Recy. 2009;54:79-85.

[22] Mourad K, Berndtsson R. Potential water saving from rainwater harvesting in Syria. VATTEN. 2011;67:113-117.

[23] Fewkes A. The use of rainwater for WC flushing: the field testing of a collection system. Build Environ. 1999;34:765-772.

[24] European Commission: Study on water performance of buildings. Reference Report 070307/2008/520703/ETU/D2, 2009.

[25] Butler D, Memon A, Makropoulos C, Southall A, Clarke L. Guidance on Water Cycle Management for New Developments. CIRIA Report C690. London: CIRIA; 2010.

[26] Pandey DN, Gupta AK, Anderson DM. Rainwater harvesting as an adaptation to climate change. Current Sci. 2003;85(1):46-59. 
[27] Sales JC, Konig KW, Lo A. Rainwater harvesting providing adaptation opportunities to climate change. In: Barron J, editor. Rainwater Harvesting: A Lifeline for Human Well-being. A Report Prepared for UNEP by Stockholm Environment Institute. Stockholm, Sweden: Stockholm Resilience Centre; 2009.

[28] Mwenge Kahinda J, Taigbenu AE, Boroto RJ. Domestic rainwater harvesting as an adaptation measure to climate change in South Africa. Phys Chem Earth. 2010;35:742-751.

[29] Ghisi E, Oliveira S. Potential for potable water savings by combining the use of rainwater and greywater in houses in southern Brazil. Build Environ. 2007;42:1731-1742. DOI:10.1016/j.buildenv.2006.02.001.

[30] Ghisi E. Potential for potable water savings by using rainwater in the residential sector of Brazil. Build Environ. 2006;41:1544-1550. DOI: 10.1016/j.buildenv.2005.01.014.

[31] Fewkes A. Modelling the performance of rainwater collection systems: towards a generalized approach. Urban Water. 1999;1:323-333.

[32] Ghisi E, Ferreira D. Potential for potable water savings by using rainwater and greywater in a multi-storey residential building in southern Brazil. Build Environ. 2007;42:2512-2522. DOI: 10.1016/j.buildenv.2006.07.019.

[33] Zaizen M, Urakawa T, Matsumoto Y, Takai H. The collection of rainwater from dome stadiums in Japan. Urban Water. 1999;1:355-359.

[34] Appan A. A dual-mode system for harnessing roofwater for non-potable uses. Urban Water. 1999;1:317-321.

[35] Chilton J, Maidment G, Marriott D, Francis A, Tobias G. Case study of rainwater recovery system in a commercial building with a large roof. Urban Water. 1999;1:345-354.

[36] Ward S, Memon FA, Butler D. Performance of a large building rainwater harvesting system. Water Research. 2012;46:5127-5134. DOI: 10.1016/j.watres.2012.06.043.

[37] Coombes PJ, Argus JR, Kuczera G. Figtree place: a case study in water sensitive urban development. Urban Water. 1999;1:335-343.

[38] Eroksuz E, Rahman A. Rainwater tanks in multi-unit buildings: A case study for three Australian cities. Res Conserv Recycl. 2010;54:1449-1452.

[39] Abdulla FA, Al-Shreef AW. Roof rainwater harvesting systems for household water supply in Jordan. Desalination. 2009;1:195-207.

[40] Ghisi E, Montibeller A, Schmidt RW. Potential for potable water savings by using rainwater: An analysis over 62 cities in southern Brazil. Build Environ. 2006;41:204-210.

[41] Hermann T, Schmida U. Rainwater utilization in Germany: efficiency, dimensioning, hydraulic and environmental aspects. Urban Water. 1999;1:307-316.

[42] www.rainwaterharvesting.org

[43] Souza EL, Ghisi E. Potable water savings by using rainwater for non-potable uses in houses. Water. 2012;4:607-628. DOI:10.3390/w4030607.

[44] Słyś D. Potential of rainwater utilization in residential housing in Poland. Water Environ J. 2009;23:318-325. DOI: 10.1111/j.1747-6593.2008.00159.x.

[45] Słyś D, Stec A, Zeleňáková M. A LCC analysis of rainwater management variants. Ecol Chem Eng S. 2012;19(30:359-372. DOI: 10.2478/v10216-011-0026-7.

[46] Vaes G, Berlamont J. The effect of rainwater storage tanks on design storms. Urban Water. 2001;3:303-307.

[47] Bakis N, Kagiouglou M, Aouad G, Amaratunga D, Kishk M, Al-Hajj A. An Integrated Environment for Life Cycle Costing in Construction. 2003. http://usir.salford.ac.uk/9970/1/300_Bakis_N_ AN_INTEGRATED_ENVIRONMENT_FOR.pdf

[48] Gluch P, Baumann H. The life cycle costing (LCC) approach: a conceptual discussion of its usefulness for environmental decision-making. Building Environ. 2004;39:571-580. DOI: 10.1016/j.buildenv.2003.10.008.

[49] Ghimire SR, Watkins DW, Li K. Life cycle cost assessment of a rain water harvesting system for toilet flushing. Water Science \& Technology: Water Supply. 2012;12(3):309-320. DOI: 10.2166/ws.2011.135.

[50] Farreny R, Gabarrella X, Rieradevall J. Cost-efficiency of rainwater harvesting strategies in dense Mediterranean neighbourhoods. Resour Conserv Recycling. 2011;55:686-694. DOI: 10.1016/j.resconrec.2011.01.008.

[51] Roebuck RM, Oltean-Dumbrava C, Tait S. Whole life cost performance of domestic rainwater harvesting systems in the United Kingdom. Water Environ J. 2010;25:355-365. DOI: 10.1111/j.17476593.2010.00230.x. 


\title{
ANALIZA WARIANTÓW ZAOPATRZENIA W WODE WIELORODZINNEGO BUDYNKU MIESZKALNEGO
}

Katedra Infrastruktury i Ekorozwoju, Wydział Budownictwa i Inżynierii Środowiska, Politechnika Rzeszowska

\begin{abstract}
Abstrakt: Zmiany klimatu, niewłaściwe korzystanie $\mathrm{z}$ zasobów wodnych, zanieczyszczenie wód powierzchniowych, a także zwiększające się zapotrzebowanie na wodę, które jest wynikiem rosnącej populacji ludzi, powodują, że w większości krajów na świecie, w tym również w Polsce, występuje wodny deficyt. Ze względu na zanieczyszczenie wody do jej uzdatniania wymagane są coraz bardziej zaawansowane technologie, co w efekcie prowadzi do wzrostu cen jej zakupu. W związku z tym coraz częściej podejmowane są działania, których celem jest ograniczenie zużycia wody wodociągowej m.in. poprzez wykorzystanie wód opadowych do spłukiwania toalet, mycia samochodów, prania czy nawadniania terenów zielonych. W publikacji przedstawiono wyniki analizy Life Cycle Cost dla dwóch wariantów zaopatrzenia w wodę projektowanego budynku wielorodzinnego, zlokalizowanego w Rzeszowie. Zgodnie z metodologią LCC, obliczenia wykonano w pełnym cyklu istnienia obiektu budowlanego, uwzględniając zarówno początkowe nakłady inwestycyjne przeznaczone na wykonanie instalacji wodociągowej, jak i koszty związane z jej eksploatacją. W pierwszym z analizowanych wariantów założono, że instalacja ta zasilana będzie $\mathrm{z}$ miejskiej sieci wodociągowej. Natomiast w drugim wariancie dodatkowo zastosowano instalację gospodarczego wykorzystania wód opadowych. Zmagazynowane w zbiorniku wody deszczowe zostaną wykorzystane w instalacji sanitarnej do spłukiwania toalet, co pozwoli obniżyć koszty zakupu wody wodociągowej, zmniejszyć opłaty za odprowadzanie wód opadowych do kanalizacji, i tym samym wpłynie korzystanie na wyniki finansowe funkcjonowania rozpatrywanego obiektu mieszkalnego.
\end{abstract}

Słowa kluczowe: zaopatrzenie budynków w wodę, analiza Life Cycle Cost, systemy gospodarczego wykorzystania wody opadowej 